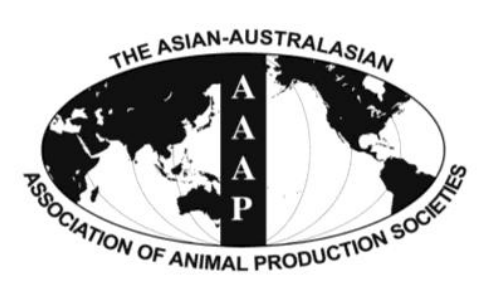

Open Access

Asian Australas. J. Anim. Sci.

Vol. 27, No. 9 : 1228-1235 September 2014

http://dx.doi.org/10.5713/ajas.2013.13567

www.ajas.info

pISSN 1011-2367 elSSN 1976-5517

\title{
Association between Genetic Polymorphism in the Swine Leukocyte Antigen-DRA Gene and Piglet Diarrhea in Three Chinese Pig Breeds
}

\author{
Q. L. Yang ${ }^{1,2}$, S. G. Zhao ${ }^{1,3}$, D. W. Wang ${ }^{1}$, Y. Feng ${ }^{1,3}$, T. T. Jiang ${ }^{1,3}$, X. Y. Huang ${ }^{1}$, and S. B. Gun ${ }^{1,3, *}$ \\ ${ }^{1}$ College of Animal Science and Technology, Gansu Agricultural University, Lanzhou 730070, China
}

\begin{abstract}
The swine leukocyte antigen (SLA)-DRA locus is noteworthy among other SLA class II loci for its limited variation and has not been investigated in depth. This study was investigated to detect polymorphisms of four exons of SLA-DRA gene and its association with piglet diarrhea in Landrace, Large White and Duroc pigs. No polymorphisms were detected in exon 3, while 2 SNPs (c.178G >A and c.211T>C), 2 SNPs (c.3093A $>C$ and c. $3104 \mathrm{C}>\mathrm{T}$ ) and 5 SNPs (c.4167A>G, c.4184A $>$ G, c. $4194 \mathrm{~A}>\mathrm{G}, \mathrm{c} .4246 \mathrm{~A}>\mathrm{G}$ and c.4293G >A) were detected in exon 1, exon 2 and exon 4 respectively, and 1 SNP (c.4081T>C) in intron 3. Statistical results showed that genotype had significant effect on piglet diarrhea, individuals with genotype $\mathrm{BC}$ had a higher diarrhea score when compared with the genotypes $\mathrm{AA}, \mathrm{AB}, \mathrm{AC}$ and $\mathrm{CC}$. Futhermore, genotype $\mathrm{AC}$ had a higher diarrhea score than the genotype $\mathrm{CC}$ in exon $1(\mathrm{p}<0.05)$; diarrhea scores of genotype AA and BB were higher than those of genotypes AC and CC in exon 2 ( $p<0.05$ ); individuals with genotype AA had a higher diarrhea score than individuals with genotype AB and BB in exon $4(\mathrm{p}<0.05)$. Fourteen common haplotypes were founded by haplotype constructing of all SNPs in the three exons, its association with piglet diarrhea appeared that Hap2, 5, 8, 10, and 14 may be the susceptible haplotypes and Hap9 may be the resistant haplotype to piglet diarrhea. The genetic variations identified of the $S L A-D R A$ gene may potentially be functional mutations related to piglet diarrhea. (Key Words: Swine Leukocyte Antigen, DRA Gene, Association, Genetic Polymorphism, Haplotype, Piglet Diarrhea)
\end{abstract}

\section{INTRODUCTION}

The major histocompatibility complex (MHC) class II molecules are tightly linked and highly polymorphic cell surface glycoproteins, which preferentially recognize foreign antigen to $\mathrm{T}$ cells and subsequently, initiate specific immune responses against infectious disease (Kedrick and Kim, 2000; Patch et al., 2011). In swine, swine leukocyte antigen (SLA) class II antigens are heterodimeric proteins that are comprised of non-covalently linked $\alpha(34 \mathrm{kDa})$ and $\beta(29 \mathrm{kDa})$ chains, with the $\alpha$ chain coded by the SLA-DRA

\footnotetext{
* Corresponding Author: S. B. Gun. Tel: +86-931-7631804, Fax: +86-931-7631239, E-mail: gunsbao056@126.com

${ }^{2}$ Animal Husbandry and Veterinary Institute of Gansu Province, Pingliang 744000, China.

${ }^{3}$ Gansu Research Center for Swine Production Engineering and Technology, Lanzhou 730070, China.

Submitted Sept. 12, 2013; Revised Dec. 30, 2013; Accepted Mar. 27, 2014
}

and $S L A-D Q A$ genes and $\beta$ chain coded by the SLA-DRBI and SLA-DQB1 genes (Lunney et al., 2009).

It is evidenced that some SLA alleles and haplotypes are associated with some immune-related diseases such as antibody responses to sheep erythrocytes and cell-mediated immune responses to tuberculin-purified protein (Mallard et al., 1989; Shinkai et al., 2012), PRRS (Lewis et al., 2007; Molina et al., 2008), and other swine immune response to various infectious agents (Renard and Vaiman, 1989; Chen et al., 2005; Ho et al., 2010a). To investigate the role of SLA genes in immune responsiveness, it is essential to have a better understanding of SLA polymorphism.

The SLA-DRA gene, which encodes the $\alpha$ chain of DR antigen is closely linked to DRB. The full-length genome sequence of $4.6 \mathrm{~kb}$, encodes for a polypeptide of 252 amino acid residues, which includes four exons and is considered to have limited allelic variation (Ho et al., 2009; Lunney et al., 2009). Therefore previous studies on genetic 
polymorphism of SLA class II genes have primarily focused on polymorphism in $D Q B, D R B$, and $D Q A$ genes (Luetkemeier et al., 2009; Ho et al., 2010a; Essler et al., 2013), but rarely targeted the swine $D R A$ gene for comprehensive analysis. Consequently, the extent of variation at the locus is not yet known.

Due to large scale intensive production systems, pigs are exposed to various pathogens that cause infectious diseases and pathological symptoms (Lunney et al., 2009). Diarrhea in newborns and pre-weaning piglets, which causes increased mortality rates, poor growth and additional medical costs, is one of the most serious threats in the swine industry. It is estimated that $50 \%$ of piglet mortality is due to diarrhea deaths (Morris et al., 2002). Our preliminary studies indicated that piglet diarrhea during pre-weaning was linked to the exon 2 of $S L A-D R A$ and $S L A-D Q A$ gene polymorphism (Yang et al., 2012; Yang et al., 2013).

The objective of this study was to detect the genetic variation of the four exon regions of the SLA-DRA gene, and investigate the association with piglet diarrhea from Landrace, Large White and Duroc pigs using polymerase chain reaction-single strand conformation polymorphism (PCR-SSCP) and sequencing, to provide a theoretical foundation for further pig anti-disease breeding.

\section{MATERIALS AND METHODS}

\section{Animals and genomic DNA extraction}

A total of 216 pure strain piglets from 24 sires were selected from Linze Xinghua Pig Breeding Farm (Zhangye, Gansu, China), including Landrace $(\mathrm{n}=72)$, Large White ( $\mathrm{n}$ $=72$ ) and Duroc $(n=72)$.

Experimental piglets were born in the same time period (within 20 days) and the experiment conducted under forage and feeding management conditions and disease control in accordance with the Guide for Chinese Feeding Standard of Swine and approved by the institute of Ministry of Agriculture Feed Industry Center, China Agricultural University (Beijing, China). All piglets were monitored two times a day during the entire suckling period (from birth to weaning, 0 to 28 days) and assigned a daily score based on visual analysis of symptoms traits as follows: 0: normal, solid feces; 1: slight diarrhea, soft and loose feces; 2: moderate diarrhea, semi-liquid feces; 3: severe diarrhea, liquid and unformed feces (Kelly et al., 1990).

Genomic DNA was isolated from swine ear tissues samples by standard phenol-chloroform extraction meth odology (Sambrook and Russell, 2001) and quantified by using a Nanodrop ND-1000 spectrophotometer (Ther mo Fisher Scientific, Wilmington, DE, USA).

\section{Polymerase chain reaction amplification and polymerase chain reaction-single strand conformation polymorphism analyses}

Four primer pairs (Table 1), were designed to amplify exons $1,2,3$ and 4 of $S L A-D R A$ gene according to the published $S L A-D R A$ gene sequence in GenBank (accession No. AY303990). PCR analyses were performed in $25 \mu \mathrm{L}$ reactions containing of $100 \mathrm{ng}$ genomic DNA, $2.5 \mu \mathrm{L}$ of 10 $\times$ PCR buffer (containing $\mathrm{Mg}^{2+}, 15 \mathrm{mM}$ ), $2.5 \mathrm{mM} \mathrm{dNTP}$ mixture, 10 pmol of each primer, and $5 \mathrm{U}$ of Taq polymerase (TaKaRa, Dalian, China). The thermal profile consisted of $2 \mathrm{~min}$ at $94^{\circ} \mathrm{C}$, followed by 35 cycles of $20 \mathrm{~s}$ at $94^{\circ} \mathrm{C}, 30 \mathrm{~s}$ at annealing temperatures (Table 1) and $30 \mathrm{~s}$ at $72^{\circ} \mathrm{C}$, with a final extension of $10 \mathrm{~min}$ at $72^{\circ} \mathrm{C}$.

For SSCP analysis, $2 \mu \mathrm{L}$ PCR products were mixed with $7 \mu \mathrm{L}$ of the denaturing solution (98\% formamide, $10 \mathrm{mM}$ ethylene diamine tetraacetic acid (EDTA), 0.0 $25 \%$ bromophenol blue, and $0.025 \%$ xylene-cyanole), af ter denaturation at $98^{\circ} \mathrm{C}$ for $10 \mathrm{~min}$, samples were coo led on ice immediately and loaded on polyacrylamide gel $(170 \times 170 \times 1 \mathrm{~mm})$ in $1 \times$ TBE under optimal conditio ns. Gels were silver-stained according to the method of Byun et al. (2009).

\section{Cloning and sequencing}

PCR products representative of different SSCP patterns were purified using DNA Fragment Quick Recover Kit (TaKaRa, Dalian, China). The purified PCR products were ligated into the pMD19-T vectors (TaKaRa, Dalian, China) according to the manufacturer's recommendations. The mixture was incubated at $4^{\circ} \mathrm{C}$ overnight, and transformed

Table 1. Primer sequences, annealing temperature $(\mathrm{Ta})$ and size of amplification products

\begin{tabular}{|c|c|c|c|c|}
\hline Locus & Primer sequence $\left(5^{\prime} \rightarrow 3^{\prime}\right)$ & $\mathrm{Ta}\left({ }^{\circ} \mathrm{C}\right)$ & Position & Size (bp) \\
\hline Exon 1 & $\begin{array}{l}\text { F: CTTTGCTTGTATTGC } \\
\text { R: ACCTAACTACCCCTC }\end{array}$ & 56.8 & $79-264$ & 186 \\
\hline Exon 2 & $\begin{array}{l}\text { F: CAGAGAATCACGTGATCAT } \\
\text { R: ACAGGTACCATTGGTGTT }\end{array}$ & 55.0 & $288-3137$ & 257 \\
\hline Exon 3 & $\begin{array}{l}\text { F: TGCTAAACAGGGAAGGCT } \\
\text { R: ACAAAGGAGACTGAGGGATG }\end{array}$ & 56.8 & $3531-3882$ & 352 \\
\hline Exon 4 & $\begin{array}{l}\text { F: TCCCGTAATACATCGTTC } \\
\text { R: TTCCTTTCCTTGGCTCAT }\end{array}$ & 55.6 & $4018-4374$ & 357 \\
\hline
\end{tabular}

Primer positions refer to SLA-DRA gene sequence in GenBank (Accession No.AY303990), exon 1, 2, 3, and 4 are located at 151-226, 2884-3129, 35733854, 4155-4309, respectively. 
into Escherichia coli DH5a strains. Recombinant clones were detected by blue/white screening, 10 to 15 insertpositive clones for each transformation were incubated overnight at $37^{\circ} \mathrm{C}$, in a vibrating rotary incubator $(200 \mathrm{rpm})$. Verification of targeted inserts were screened using the PCR-SSCP approach as described by Zhou et al. (2008), and only those clones for which the SSCP patterns matched those of the corresponding genomic DNA were selected and subsequently sequenced by Sangon Biotech (Shanghai, China) Co., Ltd.

\section{Statistical analysis}

Nucleotide and amino acid sequences were analyzed using MEGA5 (Tamura et al., 2011) and new allele sequences were submitted to GenBank database (http://www.ncbi.nlm.nih.gov/nuccore/); gene heterozygosity (He) was calculated using POPGENE software (version 3.2); polymorphism information content (PIC) was calculated by Botstein's methods (1980). Haplotype construction and linkage disequilibrium were analyzed by PHASE 2.0 (Stephens and Donnelly, 2003) and DNAsp 5.0 (Hudson, 2001) software respectively.

The effects of genotype on piglet diarrhea were analyzed using the general linear model procedure of SAS software (SAS, 1999) according to the following statistical model:

$$
\mathrm{Y}_{\mathrm{ijklm}}=\mu+\mathrm{B}_{\mathrm{i}}+\mathrm{S}_{\mathrm{j}}+\mathrm{G}_{\mathrm{k}}+\mathrm{e}_{\mathrm{ijkl}}
$$

Where $\mathrm{Y}_{\mathrm{ijkl}}$ is the observation value of piglet diarrhea score, $\mu$ is the overall population means, $B_{i}$ is the fixed effect of breed, $S_{j}$ is fixed effect of gender, $G_{k}$ is the effect of genotype, and $\mathrm{e}$ is the random residual effect. Preliminary analysis also included the fixed interaction effects of breed, sex and genotype, however, these interaction effects were subsequently removed because they did not have a significant effect.

\section{RESULTS}

\section{Genetic polymorphism of the $S L A-D R A$ gene}

There was no polymorphism in exon 3 of the DRA locus. Six genotypes were detected in exon 1 and exon 2 (Figure $1 \mathrm{~A}$ and Figure 1B), respectively. They were defined as AA, $\mathrm{AB}, \mathrm{BB}, \mathrm{AC}, \mathrm{CC}$, and $\mathrm{BC}$. For exon 1, genotypes AA, BC, $\mathrm{AC}$, and $\mathrm{CC}$ were detected in all three pig populations, genotype $\mathrm{BB}$ was only detected in Duroc. Three alleles were described as: A (A-T), B (G-C), and C (G-T) in this locus (Table 2). Allele $\mathrm{C}$ was the most common in Large White with a frequency of 0.55 , whereas allele A was predominate in Landrace and Duroc with frequencies of 0.51 and 0.44 , respectively.

For exon 2, genotypes $\mathrm{AA}, \mathrm{AB}, \mathrm{BB}$, and $\mathrm{BC}$ were detected in all three pig breeds, but no $\mathrm{AC}$ or $\mathrm{CC}$ genotype were observed in the Duroc. Three alleles were described as: A (A-C), B (C-C), and C (C-T) at this locus (Table 3). Allele B was predominant in Large White and Landrace with frequencies of 0.51 and 0.61 , respectively. The frequency of allele A (0.49) was identical with allele B in Duroc.

Seven different genotypes (AA, AB, BB, BC, BC, BD, $\mathrm{CE}$, and $\mathrm{CF}$ ) were identified in exon 4 of the $D R A$ locus (Figure 1C). Seven genotypes were evident in the Large White and Landrace, but only genotypes $\mathrm{AA}, \mathrm{AB}$, and $\mathrm{CE}$ were detected in Duroc. Seven alleles were described as: A (T-A-A-A-G-G), B (T-G-A-A-G-G), C (C-A-A-A-G-G), D (T-A-A-A-A-G), E (T-A-A-G-G-A), and F (T-G-G-A-G-G) (Table 4). A was the most common allele in the three breeds with frequencies of $0.52,0.54$, and 0.90 , respectively.

Results of genetic indexes ( $\mathrm{He}$ and $\mathrm{PIC}$ ) indicated that all PIC values ranged from 0.4 to 0.59 (Tables 2,3 , and 4) with the exception of low polymorphism in Duroc in exon 4 site $(P I C=0.19)$ (Table 4$)$ indicating all of these loci exhibited abundant genetic diversity within the different pig strains according to the protocol of Vaiman et al. (1994).
A

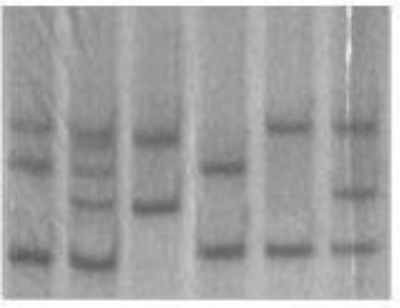

$B C \quad A B \quad A A \quad B B \quad C C A C$
B

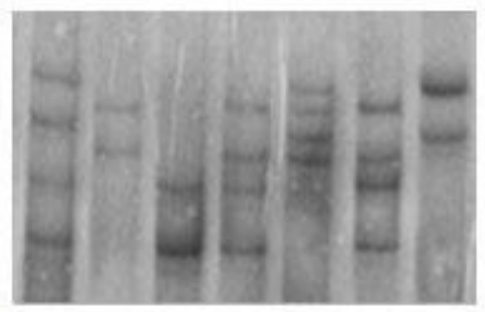

$A B \quad C C \quad B B \quad B C \quad A C \quad B C \quad A A$
C

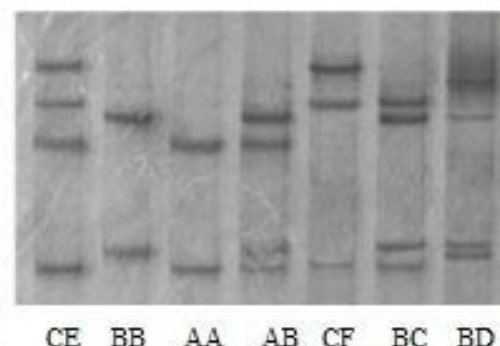

Figure 1. PCR-SSCP analysis of PCR amplified products for exon 1, exon 2, and exon 4 of the SLA-DRA gene, respectively. Exon 3 with no polymorphism detected in the amplification region is not listed in this figure. (A) PCR-SSCP band patterns for exon 1 on $12 \%$ acrylamide:bisacrylamide gel (39:1) after $10 \mathrm{~min}(250 \mathrm{~V})$ and then $20 \mathrm{~h}(200 \mathrm{~V})$ of the run at $4^{\circ} \mathrm{C},(\mathrm{B}) \mathrm{PCR}-\mathrm{SSCP}$ band patterns for exon 2 on $10 \%$ acrylamide:bisacrylamide gel $(29: 1)$ after $30 \mathrm{~min}(250 \mathrm{~V})$ and then $20 \mathrm{~h}(200 \mathrm{~V})$ of the run at $4^{\circ} \mathrm{C}$, (C) PCR-SSCP band patterns exon 4 on $10 \%$ acrylamide:bisacrylamide gel $(29: 1)$ after $30 \mathrm{~min}(250 \mathrm{~V})$ and then $20 \mathrm{~h}(200 \mathrm{~V})$ of the run at $12^{\circ} \mathrm{C}$. PCR-SSCP, polymerase chain reaction-single strand conformation polymorphism. 
Table 2. Genotype and allele frequency, $H e$ and $P I C$ of the SLA-DRA exon 1 in the three pig strains

\begin{tabular}{|c|c|c|c|c|c|c|}
\hline \multirow{2}{*}{ Exon1 } & & \multicolumn{2}{|c|}{ GenBank (No.AY303990) 5' $\rightarrow 3^{\prime}$} & \multicolumn{3}{|c|}{ Frequency } \\
\hline & & 178 & 211 & Large White & Landrace & Duroc \\
\hline \multirow[t]{6}{*}{ Genotype } & AA & A & $\mathrm{T}$ & $0.17(12)$ & $0.13(9)$ & $0.18(13)$ \\
\hline & $\mathrm{AB}$ & $\mathrm{A} / \mathrm{G}$ & $\mathrm{T} / \mathrm{C}$ & $0.01(1)$ & $0.06(4)$ & $0.35(25)$ \\
\hline & $\mathrm{BB}$ & $\mathrm{G}$ & $\mathrm{C}$ & $0(0)$ & $0(0)$ & $0.10(7)$ \\
\hline & $\mathrm{BC}$ & G & $\mathrm{T} / \mathrm{C}$ & $0.04(3)$ & $0.04(3)$ & $0.11(8)$ \\
\hline & $\mathrm{AC}$ & $\mathrm{A} / \mathrm{G}$ & $\mathrm{T}$ & $0.50(36)$ & $0.71(51)$ & $0.17(12)$ \\
\hline & $\mathrm{CC}$ & $\mathrm{G}$ & $\mathrm{T}$ & $0.28(20)$ & $0.07(5)$ & $0.10(7)$ \\
\hline \multirow[t]{3}{*}{ Allele } & A & A & $\mathrm{T}$ & 0.42 & 0.51 & 0.44 \\
\hline & $\mathrm{B}$ & G & $\mathrm{C}$ & 0.03 & 0.05 & 0.33 \\
\hline & $\mathrm{C}$ & G & $\mathrm{T}$ & 0.55 & 0.44 & 0.24 \\
\hline $\mathrm{He}$ & & & & 0.51 & 0.54 & 0.67 \\
\hline PIC & & & & 0.40 & 0.44 & 0.57 \\
\hline
\end{tabular}

$\mathrm{He}$, observed heterozygosity; PIC, polymorphism information content; SLA, swine leukocyte antigen. The following marker means are same. Numbers in brackets are population size tested that belong to the respective genotypes. Bases in the boxes are mutation bases in amplified regions.

The PIC and $\mathrm{He}$ for Duroc pigs were lower than Large White and Landrace in exon 4 locus, which is not unexpected. However, it may be explained by the differences in genetic backgrounds as well as selection pressures between Duroc and Large White, Landrace.

\section{Nucleotide and amino acid variation}

The nucleotide characterizations were investigated by cloning and sequencing. According to references sequence AY303990 of SLA-DRA gene, two SNPs (c.178G>A and c.211T $>$ C) and two SNPs (c.3093A $>C$ and c.3104C $>$ T) were detected in exon 1 and exon 2, respectively (Tables 2 and 3). Additionally, in exon 4 locus, one SNP (c.4081T >C) in intron 3 and five SNPs (c.4167A $>\mathrm{G}, \quad$ c.4184A $>\mathrm{G}$, c. $4194 \mathrm{~A}>\mathrm{G}, \mathrm{c} .4246 \mathrm{~A}>\mathrm{G}$, and c.4293G $>\mathrm{A}$ ) in exon 4 were detected (Table 4). When compared with the existing SLA$D R A$ alleles in the Immuno Polymorphism Database (IPD)-
MHC SLA sequence database (http://www.ebi.ac.uk/ipd/ mhc/sla/), mutations c. $178 \mathrm{G}>\mathrm{A}, \quad$ c. $211 \mathrm{~T}>\mathrm{C}, \quad$ c. $4081 \mathrm{~T}>\mathrm{C}$ c. $4184 \mathrm{~A}>\mathrm{G}$ and c. $4293 \mathrm{G}>\mathrm{A}$ were found for the first time in swine, which formed four new allele sequences and have been submitted to the GenBank database (http://www.ncbi.nlm.nih.gov/nuccore/) and assigned the accession number JX135565, JX135566, JX135567, and JX135568.

\section{Effects of genotypes and haplotypes on piglet diarrhea}

Results shows differences at $S L A-D R A$ exon 1 and exon 2 loci for genotype and piglet diarrhea $(\mathrm{p}<0.05)$ (Table 5). The least square means along with standard errors for piglet diarrhea score among different genotypes are given in Table 6.

In exon 1 , the individuals with genotype $\mathrm{BC}$ showed a higher diarrhea score $(1.77 \pm 0.28)$ than those with genotypes

Table 3. Genotype and allele frequency, $H e$ and $P I C$ of the $S L A-D R A$ exon 2 in the three pig strains

\begin{tabular}{|c|c|c|c|c|c|c|}
\hline \multirow{2}{*}{ Exon2 } & & \multicolumn{2}{|c|}{ GenBank (No.AY303990) 5' $\rightarrow 3^{\prime}$} & \multicolumn{3}{|c|}{ Frequency } \\
\hline & & 3093 & 3104 & Large White & Landrace & Duroc \\
\hline \multirow{7}{*}{ Genotype } & & & & & & \\
\hline & AA & $\mathrm{A}$ & $\mathrm{C}$ & $0.13(9)$ & $0.08(6)$ & $0.21(15)$ \\
\hline & $\mathrm{AB}$ & $\mathrm{A} / \mathrm{C}$ & $\mathrm{C}$ & $0.33(24)$ & $0.33(24)$ & $0.57(41)$ \\
\hline & BB & $\mathrm{C}$ & $\mathrm{C}$ & $0.26(19)$ & $0.38(27)$ & $0.18(13)$ \\
\hline & $\mathrm{BC}$ & $\mathrm{C}$ & $\mathrm{C} / \mathrm{T}$ & $0.17(12)$ & $0.14(10)$ & $0.04(3)$ \\
\hline & $\mathrm{AC}$ & $\mathrm{A} / \mathrm{C}$ & $\mathrm{C} / \mathrm{T}$ & $0.07(5)$ & $0.06(4)$ & $0(0)$ \\
\hline & $\mathrm{CC}$ & $\mathrm{C}$ & $\mathrm{T}$ & $0.04(3)$ & $0.01(1)$ & $0(0)$ \\
\hline \multirow[t]{3}{*}{ Allele } & A & A & $\mathrm{C}$ & 0.33 & 0.28 & 0.49 \\
\hline & $\mathrm{B}$ & $\mathrm{C}$ & $\mathrm{C}$ & 0.51 & 0.61 & 0.49 \\
\hline & $\mathrm{C}$ & $\mathrm{C}$ & $\mathrm{T}$ & 0.16 & 0.11 & 0.02 \\
\hline $\mathrm{He}$ & & & & 0.61 & 0.54 & 0.52 \\
\hline PIC & & & & 0.53 & 0.47 & 0.40 \\
\hline
\end{tabular}

$\mathrm{He}$, observed heterozygosity; PIC, polymorphism information content; SLA, swine leukocyte antigen. 
Table 4. Genotype and allele frequency, $H e$ and PIC of the SLA-DRA exon 4 in the three pig strains

\begin{tabular}{|c|c|c|c|c|c|c|c|c|c|c|}
\hline \multirow{2}{*}{ Exon4 } & & \multicolumn{6}{|c|}{ GenBank (No. AY303990) 5' $\rightarrow 3^{\prime}$} & \multicolumn{3}{|c|}{ Frequency } \\
\hline & & 4081 & 4167 & 4184 & 4194 & 4246 & 4293 & Large White & Landrace & Duroc \\
\hline \multirow{8}{*}{ Genotype } & & & & & & & & & & \\
\hline & AA & $\mathrm{T}$ & A & A & A & $\mathrm{G}$ & G & $0.35(25)$ & $0.43(31)$ & $0.85(61)$ \\
\hline & $\mathrm{AB}$ & $\mathrm{T}$ & $\mathrm{A} / \mathrm{G}$ & A & A & $\mathrm{G}$ & G & $0.35(25)$ & $0.22(16)$ & $0.97(7)$ \\
\hline & $\mathrm{BB}$ & $\mathrm{T}$ & G & A & A & G & G & $0.07(5)$ & $0.06(4)$ & $0(0)$ \\
\hline & $\mathrm{BC}$ & $\mathrm{T} / \mathrm{C}$ & $\mathrm{A} / \mathrm{G}$ & A & A & $\mathrm{G}$ & G & $0.10(7)$ & $0.06(4)$ & $0(0)$ \\
\hline & $\mathrm{BD}$ & $\mathrm{T}$ & $\mathrm{A} / \mathrm{G}$ & A & A & $\mathrm{A} / \mathrm{G}$ & G & $0.01(1)$ & $0.01(1)$ & $0(0)$ \\
\hline & $\mathrm{CE}$ & $\mathrm{T} / \mathrm{C}$ & A & A & $\mathrm{A} / \mathrm{G}$ & $\mathrm{G}$ & $\mathrm{G} / \mathrm{A}$ & $0.08(6)$ & $0.18(13)$ & $0.06(4)$ \\
\hline & $\mathrm{CF}$ & $\mathrm{T} / \mathrm{C}$ & $\mathrm{A} / \mathrm{G}$ & $\mathrm{A} / \mathrm{G}$ & A & $\mathrm{G}$ & $\mathrm{G}$ & 0.04 (3) & $0.04(3)$ & $0(0)$ \\
\hline \multirow[t]{6}{*}{ Allele } & A & $\mathrm{T}$ & A & A & A & G & $\mathrm{G}$ & 0.52 & 0.54 & 0.90 \\
\hline & B & $\mathrm{T}$ & G & A & A & G & $\mathrm{G}$ & 0.30 & 0.20 & 0.05 \\
\hline & $\mathrm{C}$ & $\mathrm{C}$ & A & A & A & G & $\mathrm{G}$ & 0.11 & 0.14 & 0.03 \\
\hline & $\mathrm{D}$ & $\mathrm{T}$ & A & A & A & A & G & 0.01 & 0.01 & 0 \\
\hline & $\mathrm{E}$ & $\mathrm{T}$ & A & A & G & G & A & 0.04 & 0.09 & 0.03 \\
\hline & $\mathrm{F}$ & $\mathrm{T}$ & G & G & A & G & $\mathrm{G}$ & 0.02 & 0.02 & 0 \\
\hline $\mathrm{He}$ & & & & & & & & 0.63 & 0.64 & 0.19 \\
\hline$P I C$ & & & & & & & & 0.57 & 0.59 & 0.19 \\
\hline
\end{tabular}

$H e$, observed heterozygosity; PIC, polymorphism information content; SLA, swine leukocyte antigen. SNP c.4081T $>C$ was found in intron 3.

Table 5. Effects of different factors on piglet diarrhea score

\begin{tabular}{|c|c|c|c|c|c|c|c|c|c|}
\hline \multirow{2}{*}{ Factors } & \multicolumn{3}{|c|}{ Exon1 } & \multicolumn{3}{|c|}{ Exon2 } & \multicolumn{3}{|c|}{ Exon4 } \\
\hline & Breed & Sex & Genotype & Breed & Sex & Genotype & Breed & Sex & Genotype \\
\hline F value & 0.65 & 0.01 & 3.21 & 0.34 & 0.02 & 2.12 & 0.65 & 0.03 & 1.58 \\
\hline $\mathrm{p}$ & 0.52 & 0.93 & $0.008 *$ & 0.71 & 0.90 & $0.04 *$ & 0.52 & 0.86 & 0.16 \\
\hline
\end{tabular}

* Significant at 0.05 level.

AA (0.69 \pm 0.18$), \mathrm{AB}(0.85 \pm 0.21), \mathrm{AC}(0.97 \pm 0.11)$ and $\mathrm{CC}$ $(0.52 \pm 0.19)$, and genotype AC showed a higher diarrhea score $(0.97 \pm 0.11)$ than the genotype CC $(0.52 \pm 0.19)$ $(\mathrm{p}<0.05)$. In exon 2, diarrhea score of genotypes AA $(1.12 \pm 0.19)$ and $\mathrm{BB}(1.07 \pm 0.14)$ were significantly higher than those of $\mathrm{AC}(0.22 \pm 0.35)$ and $\mathrm{CC}(-0.40 \pm 0.53)$ $(\mathrm{p}<0.05)$. In exon 4 , although the observed significance level for the $\mathrm{F}$ test was 0.1552, the genotypic linear contrasts suggested that diarrhea score was higher in the AA genotype $(1.06 \pm 0.10)$ than $\mathrm{AB}(0.59 \pm 0.16)$ and $\mathrm{BB}$ $(0.29 \pm 0.35)$ genotypes $(p<0.05)$. The animals with genotype
BD were excluded when association analysis was carried out because the sample size was less than three.

Haplotype construction of all SNPs in the three exons and its association with piglet diarrhea are analyzed in Table 7. A total of 54 haplotypes were found, 14 of which had frequencies greater than $2 \%$ and were defined as common haplotypes while the others were combined in this study (Breast Cancer Association Consortium, 2006). Diarrhea individuals were mainly distributed in Hap2, 5, 8, 10, and 14 , which takes $47.92 \%$ of the total diarrhea individuals (46/96), therefore, those 5 haplotypes may be susceptible to

Table 6. Effects of different genotypes on piglet diarrhea score

\begin{tabular}{|c|c|c|c|c|c|c|c|c|}
\hline \multicolumn{3}{|c|}{ Exon1 } & \multicolumn{3}{|c|}{ Exon2 } & \multicolumn{3}{|c|}{ Exon4 } \\
\hline Genotype & Number & $\mathrm{LSM} \pm \mathrm{SE}$ & Genotype & Number & $\mathrm{LSM} \pm \mathrm{SE}$ & Genotype & Number & $\mathrm{LSM} \pm \mathrm{SE}$ \\
\hline $\mathrm{AA}$ & 34 & $0.69 \pm 0.18^{\mathrm{bc}}$ & $\mathrm{AA}$ & 30 & $1.12 \pm 0.19^{\mathrm{a}}$ & $\mathrm{AA}$ & 117 & $1.06 \pm 0.10^{\mathrm{a}}$ \\
\hline $\mathrm{BB}$ & 7 & $0.83 \pm 0.41^{\mathrm{abc}}$ & $\mathrm{BB}$ & 59 & $1.07 \pm 0.14^{\mathrm{a}}$ & $\mathrm{BB}$ & 9 & $0.29 \pm 0.35^{b}$ \\
\hline $\mathrm{AB}$ & 30 & $0.85 \pm 0.21^{\mathrm{bc}}$ & $\mathrm{AB}$ & 89 & $0.83 \pm 0.11^{\mathrm{ab}}$ & $\mathrm{AB}$ & 48 & $0.59 \pm 0.16^{\mathrm{b}}$ \\
\hline $\mathrm{BC}$ & 14 & $1.77 \pm 0.28^{\mathrm{a}}$ & $\mathrm{BC}$ & 25 & $0.79 \pm 0.21^{\mathrm{ab}}$ & $\mathrm{BC}$ & 11 & $0.76 \pm 0.32^{\mathrm{ab}}$ \\
\hline $\mathrm{AC}$ & 99 & $0.97 \pm 0.11^{b}$ & $\mathrm{AC}$ & 9 & $0.22 \pm 0.35^{\mathrm{b}}$ & $\mathrm{BD}$ & 2 & $0.97 \pm 0.74^{\mathrm{ab}}$ \\
\hline $\mathrm{CC}$ & 32 & $0.52 \pm 0.19^{c}$ & $\mathrm{CC}$ & 4 & $-0.40 \pm 0.53^{\mathrm{b}}$ & $\mathrm{CE}$ & 23 & $1.05 \pm 0.22^{\mathrm{ab}}$ \\
\hline & & & & & & $\mathrm{CF}$ & 6 & $0.63 \pm 0.43^{\mathrm{ab}}$ \\
\hline
\end{tabular}

$\mathrm{LSM} \pm \mathrm{SE}$, Diarrhea score was estimated for each genotype class and shown as means least square means \pm standard error.

${ }^{\mathrm{a}, \mathrm{b}}$ Values with different superscripts within the same line differ significantly at $\mathrm{p}<0.05$. 
Table 7. SLA-DRA gene haplotype and its association with piglet diarrhea

\begin{tabular}{|c|c|c|c|c|}
\hline \multirow{2}{*}{ Name } & \multirow{2}{*}{ Haplotypes } & \multirow{2}{*}{ Frequency $(\%)$} & \multicolumn{2}{|c|}{ Diarrhea piglets } \\
\hline & & & Number & Frequency $(\%)$ \\
\hline Hap1 & ATACTAAAGG & 8.63 & 4 & 4.17 \\
\hline Hap2 & ATACTGAAGG & 4.27 & 7 & 7.29 \\
\hline Hap3 & ATCCTGAAGG & 2.60 & 1 & 1.04 \\
\hline Hap4 & GTACTAAAGG & 8.89 & 3 & 3.13 \\
\hline Hap5 & GTACTGAAGG & 4.13 & 8 & 8.33 \\
\hline Hap6 & GTACCAAGGA & 2.08 & 4 & 4.17 \\
\hline Hap7 & GTCCTAAAGG & 9.67 & 4 & 4.17 \\
\hline Hap8 & GTCCTGAAGG & 8.13 & 13 & 13.54 \\
\hline Hap9 & GTCCCAAGGA & 2.64 & 0 & 0 \\
\hline Hap10 & GTCTTAAAGG & 6.25 & 10 & 10.42 \\
\hline Hap11 & GTCTCAAGGA & 3.28 & 3 & 3.12 \\
\hline Hap12 & GTCTCGGAGG & 2.64 & 3 & 3.12 \\
\hline Hap13 & GCACTGAAGG & 6.64 & 5 & 5.21 \\
\hline Hap14 & GCCCTAAAGG & 6.54 & 8 & 8.33 \\
\hline Others & & 23.61 & 23 & 23.96 \\
\hline
\end{tabular}

SLA, swine leukocyte antigen.

piglet diarrhea; no diarrhea piglets were in Hap9, it may be the resistant haplotype.

\section{DISCUSSION}

\section{Genetic polymorphism of the $S L A-D R A$ gene}

Early studies have described limited variation in the $S L A-D R A$ locus for the NIH miniature pig (Sachs et al., 1988; Chardon et al., 1999), but subsequent researches revealed that $S L A-D R A$ locus exhibits limited polymorphism with 13 alleles representing 3 allele groups, compared with other SLA class II genes (Ho et al., 2009; Lunney et al., 2009; Ho et al., 2010b). In this study, we detected polymorphisms throughout the entire four exon regions of $S L A-D R A$ gene firstly, 3, 2, and 6 nucleotide mutations were detected in exon 1 , exon 2 , and exon 4 of $D R A$ gene, respectively, which confirmed the result of Ho et al. (2009) and Lunney et al. (2009) who showed that the $S L A-D R A$ gene is polymorphic.

Moreover, data on SLA class II genes now predicts that the determinants of antigen binding reside in exon 2 (Chardon et al., 2000). In the SLA-DRA locus, to date only two polymorphic sites have been found in the $\alpha 1$ domain (exon 2). One is an A, C, or G (the $\mathrm{G}$ has only been found in one allele) mutation, which results in a substitution of a methionine, leucine, or valine, respectively. The second is a $\mathrm{C}$ or $\mathrm{T}$ which both code for an arginine. The two SNPs (c.3093A $>C$ and c.3104C $>\mathrm{T}$ ) detected in our study are accord with the $\mathrm{A}$ and $\mathrm{C}$ polymorphisms and the $\mathrm{C}$ and $\mathrm{T}$ polymorphism. The only two nucleotide mutations in this region may be attributed to the conservative property of $S L A-D R A$ gene, these conservative substitutions result from the survival of only mutations that retain the the crucial function of SLA-DRA gene in regulation of immunity, its conservative property is a result of evolutionary selection.

Only two homozygous genotypes (AA and $\mathrm{BB}$ ) were present in exon 4 of the $S L A-D R A$ gene, alleles $\mathrm{C}, \mathrm{D}, \mathrm{E}$, and $\mathrm{F}$ exist in heterozygous forms. There are two factors contributing to this: i) there could be a selection effect as these alleles have negative effects on individual performance, heterozygous individuals have a greater advantage over homozygous against a variety of pathogens (Sommer et al., 2005), consequently the missing homozygous genotypes may have been eliminated in the breeding process (Beuzen et al., 2000); ii) there could be a sampling effect because the sample sizes were relatively small and few homozygous animals with these alleles were expected. Thus, this polymorphism mechanism may be a necessity for resisting environment stress and maintaining normal function of SLA-DRA gene.

\section{Effects of genotypes on piglet diarrhea}

Previously studies have established that piglet mortality rate during pre-weaning caused by diarrhea was linked to SLA haplotype (Renard and Vaiman, 1989). Our current study reported that the diarrhea score of the $D Q A$ exon 2 genotype $\mathrm{CC}(0.36 \pm 0.19)$ was significantly lower than $\mathrm{AB}$ $(0.98 \pm 0.09), \mathrm{BB}(0.85 \pm 0.77), \mathrm{BC}(1.25 \pm 0.23)$ and $\mathrm{BE}$ (1.19 \pm 0.19$)$ (Yang et al., 2013). In the present study, our analysis also revealed significant differences in the score of piglet diarrhea among different genotypes of SLA-DRA gene, this supports the previous observations by Renard and Vaiman (1989) and Yang et al. (2013).

The DRA gene is located at the most centromeric of SLA II gene cluster, encodes the $\alpha$ chain with $D Q A$ gene. The presence of a small number of haplotypes shared by 
multiple individuals is indicative of linkage disequilibrium (LD). Our research group had observed a significant association between $D Q A$ gene and piglet diarrhea relating to nucleotide mutations c. $4086 \mathrm{~A}>\mathrm{G}$ and c.4087C $>\mathrm{T}$, c. $4089 \mathrm{~A}>\mathrm{G}$ and c.4090C $>\mathrm{T}$ as linked codons variation in allele $\mathrm{C}$ of Large White, Landrace and Duroc pigs (Yang et al., 2013). According to the results of Yang et al. (2013), linkage disequilibrium analysis between the exon 2 loci of $S L A-D R A-D Q A$ gene revealed five haplotypes of DRA*ADQA*B, DRA*B-DQA*B, DRA*B-DQA*C, DRA*B$\mathrm{DQA}^{*} \mathrm{D}, \mathrm{DRA} * \mathrm{C}-\mathrm{DQA} * \mathrm{~B}$. Absolute value of $\mathrm{D}^{\prime}$ and $\mathrm{r}^{2}$ for all SNP loci between $D Q A$ and $D R A$ gene showed that of the 210 pairwise comparisons, 95 showed significant LD at $\mathrm{p}<0.01$ level, indicating the comprising haplotypes of $S L A$ $D Q A$ and $D R A$ gene are in complete linkage disequilibrium $\left(\left|\mathrm{D}^{\prime}\right|=1.0000, \mathrm{r}^{2}=0.7952\right)$. In this study, we obtained SNPs in SLA-DRA gene and significant genetic correlation with piglet diarrhea were found in these 3 observed pig breeds, which together may explain the linkage of those two SLA II $\alpha$ chain markers reflecting the important function in disease resistance.

Amino acid mutations in coding regions have significant impact on the stability of proteins, which largely depend on the chemical and physical properties of mutation amino acid (molecular weight, volume and hydrophobic), mutation position (whether in transmembrane domain), and charge properties (Wang and Moult, 2001). The mutations in this study were associated with three synonymous mutations and seven non-synonymous mutations, in which c. $178 \mathrm{G}>\mathrm{A}$ and $\mathrm{c} .4167 \mathrm{~A}>\mathrm{G}$ both caused changes of uncharged amino acids to positively charged amino acid (p.10Gly>Arg, p.206Gln>Arg), and c.211T >C and c. $4184 \mathrm{~A}>\mathrm{G}$ which resulted in a hydrophilic amino acid change to hydrophobic amino acid (p.21Ser>Pro, p.212Thr $>$ Ala). Especially, the function of transmembrane protein is influenced by single peptide, c.178G $>$ A that occurred in highly hydrophobic areas of the $S L A-D R A$ single peptide region, and results in a change of hydrophobic residual base to hydrophilic and therefore may lead to the functional loss of this peptide. These are notable variations as they not only occurred in an important functional region but also caused changes in amino acid properties. The constructed haplotypes of all SNPs in the three exons and their association with piglet diarrhea revealed that haplotypes Hap2 (ATACTGAAGG), Hap5 (GTACTGAAGG), Hap8 (GTCCTGAAGG), Hap10 (GTCTTAAAGG) and Hap14 (GCCCTAAAGG) may be the susceptible haplotypes to piglet diarrhea and Hap9 (GTCCCAAGGA) may be the resistant haplotype. The nucleotide substitutions may be linked to variations of each other. Thus, we ought to focus on optimizing individuals of Hap9 and firstly eliminating individuals of Hap2, 5, 8, 10, and 14 in molecular breeding.
In conclusion, the present study firstly reports five novel SNPs within the exon regions of the SLA-DRA gene, which will provide more genetic information on the SLA-DRA gene variation. Our data revealed that these detected SNPs significantly influenced piglet diarrhea, and could be used as potential genetic markers for application in pig disease resistance breeding.

\section{ACKNOWLEDGMENTS}

This study is supported by Bio-Technology Special Program of Agriculture and Animal Husbandry of Gansu Province, China (Grant No.GNSW-2008-04, No.092NKDA036 and No.0804NKCA065) and Natural Science Foundation of China (Grant No.31101682). We sincerely thank Prof. Michael Adrian Brown (Grassland Research Laboratory, USDA-ARS, EL Reno, OK, USA) for his assistance in manuscript writing.

\section{REFERENCES}

Beuzen, N. D., M. J. Stear, and K. C. Chang. 2000. Molecular markers and their use in animal breeding. Vet. J. 160:42-52.

Breast Cancer Association Consortium. 2006. Commonly studied single-nucleotide polymorphisms and breast cancer: Results from the breast cancer association consortium. J. Natl. Cancer Inst. 98:1382-1396.

Botstein, D., R. L. White, M. Skolnick, and R. W. Davis. 1980. Construction of a genetic linkage map in man using restriction fragment length polymorphisms. Am. J. Hum. Genet. 32:314331.

Byun, S. O., Q. Fang, H. Zhou, and J. G. H. Hickford. 2009. An effective method for silver-staining DNA in large numbers of polyacrylamide gels. Anal. Biochem. 385:174-175.

Chardon, P., C. Renard, and M. Vaiman. 1999. The major histocompatibility complex in swine. Immunol. Rev. 167:179192.

Chardon, P., C. Renard, C. R. Gaillard, and M. Vaiman. 2000. The porcine major histocompatibility complex and related paralogous regions: A review. Genet. Sel. Evol. 32:109-128.

Chen, F. X., J. Xie, Y. Zhou, N. L. Li, and K. Y. Chou. 2004. Novel SLA-DR alleles of three Chinese pig strains and the related function in human T cell response. Cell. Mol. Immunol. 1:212-218.

Essler, S. E., W. Ertl, J. Deutsch, B. C. Ruetgen, S. Groiss, M. Stadler, B. Wysoudil, W. Gerner, C. S. Ho, and A. Saalmueller. 2013. Molecular characterization of swine leukocyte antigen gene diversity in purebred Pietrain pigs. Anim. Genet. 44:202205.

Hedrick, P. W. and T. J. Kim. 2000. Genetics of complex polymorphisms: Parasites and maintenance of MHC variation. In: Evolutionary Genetics from Molecules to Morphology (Eds. R. S. Singh and C. B. Krimbas). Cambridge, NY, USA. pp. 204-234.

Ho, C. S., J. K. Lunney, A. Ando, C. Rogel-Gaillard, J. H. Lee, L. B. Schook, and D. M. Smith. 2009. Nomenclature for factors 
of the SLA system, update 2008. Tissue Antigens 73:307-315. Ho, C. S., G. W. Martens, M. S. Amoss Jr, L. N. Gomez-Raya, C. W. Beattie, and D. M. Smith. 2010a. The SLA alleles and haplotypes present in Sinclair and Hanford swine. Dev. Comp. Immunol. 34:250-257.

Ho, C. S., J. K. Lunney, J. H. Lee, M. H. Franzo-Romain, G. W. Martens, R. R. Rowland, and D. M. Smith. 2010b. Molecular characterization of swine leucocyte antigen class II genes in outbred pig populations. Anim. Genet. 41:428-432.

Hudson, R. R. 2001. Linkage Disequilibrium and Recombination. In: Handbook of Statistical Genetics. In: Handbook of Statistical Genetics (Eds. D. J. Balding, M. Bishop, and C. Cannings). John Wiley and Sons, Ltd., Chichester, UK. pp. 309-324.

Kelly, D. J., J. J. O'Brien, and K. J. McCracken. 1990. Effect of creep feeding on the incidence, duration and severity of postweaning diarrhea in pigs. Res. Vet. Sci. 49:223-228.

Lewis, C. R., T. Ait-Ali, M. Clapperton, A. L. Archibald, and S. Bishop. 2007. Genetic perspectives on host responses to porcine reproductive and respiratory syndrome (PRRS). Viral Immunol. 20:343-358.

Luetkemeier, E. S., R. S. Malhi, J. E. Beever, and L. B. Schook. 2009. Diversification of porcine MHC class II genes: evidence for selective advantage. Immunogenetics 61:119-129.

Lunney, J. K., C. S. Ho, M. Wysocki, and D. M. Smith. 2009. Molecular genetics of the swine major histocompatibility complex, the SLA complex. Dev. Comp. Immunol. 33:362-374.

Mallard, B. A., B. N. Wilkie, and B. W. Kennedy. 1989. Genetic and other effects on antibody and cell mediated immune response in swine leucocyte antigen (SLA)-defined miniature pigs. Anim. Genet. 20:167-178.

Molina, R. M., S. H. Cha, W. Chittick, S. Lawson, M. P. Murtaugh, E. A. Nelson, J. Christopher-Hennings, K. J. Yoon, R. Evans, R. R. R. Rowland, and J. J. Zimmerman. 2008. Immune response against porcine reproductive and respiratory syndrome virus during acute and chronic infection. Vet. Immunol. Immunopathol. 126:283-292.

Morris, R. S., P. R. Davies, and D. E. Lawton. 2002. Evolution of diseases in the world's pig industry. In: 17th International Pig Veterinary Society Congress Proceedings, Ames, IA, USA. pp. $1-10$.

Patch, J. R., L. E. Pedersen, F. N. Toka, M. Moraes, M. J. Grubman, M. Nielsen, G. Jungersen, B. Soren, and W. T. Golde. 2011. Induction of foot-and-mouth disease virus-specific cytotoxic T cell killing by vaccination. Clin. Vaccine Immunol. 18:280-288.
Renard, C. and M. Vaiman. 1989. Possible relationships between SLA and porcine reproduction. Reprod. Nutr. Dev. 29:569-576.

Sachs, D. H., S. Germana, M. Ei-Gamil, K. Gustafsson, F. Hirsch, and K. Pratt. 1988. Class II genes of miniature swine. Immunogeneties 28:22-29.

Sambrook, J. and D. W. Russell. 2001. Molecular Cloning: A Laboratory Manual 3rd ed. Cold Spring Harbor: Cold Spring Harbor Laboratory Press.

SAS. 1999. SAS User's Guide: Statistics (Version 8.01 Ed.). SAS Institute. Inc., Cary, NC, USA.

Shinkai, H., A. Arakawa, M. Tanaka-Matsuda, H. Ide-Okumura, K. Terada, M. Chikyu, T. Kawarasaki, A. Ando, and H. Uenishi. 2012. Genetic variability in swine leukocyte antigen class II and Toll-like receptors affects immune responses to vaccination for bacterial infections in pigs. Comp. Immunol. Microbiol. Infect. Dis. 35:523-532.

Sommer, S. 2005. The importance of immune gene variability (MHC) in evolutionary ecology and conservation. Front. Zool. $2: 16$.

Stephens, M. and P. Donnelly. 2003. A comparison of Bayesian methods for haplotype reconstruction from population genotype data. Am. J. Hum. Genet. 73:1162-1169.

Tamura, K., D. Peterson, N. Peterson, G. Stecher, M. Nei, and S. Kumar. 2011. MEGA5: molecular evolutionary genetics analysis using maximum likelihood, evolutionary distance, and maximum parsimony methods. Mol. Biol. Evol. 28:2731-2739.

Vaiman, D., D. Mecier, K. Moazami-Goudarzi, A. Eggen, R. Ciampolini, A. Lepingle, R. Velmala, J. Kaukinen, S. L. Varvio, and P. Martin. 1994. A set of 99 cattle microsatellites: characterization, synteny mapping, and polymorphism. Mamm. Genome 5:288-297.

Wang, Z. and J. Moult. 2001. SNPs, proteins structer, and disease. Hum. Mutat. 17:263-270.

Yang, Q. L., J. J. Kong, S. G. Zhao, L. X. Liu, D. W. Wang, F. S. Li, T. T. Jiang, and Y. Feng. 2012. Polymorphism of SLA-DRA gene exon 2 and its correlation with piglet diarrhea. Acta Vet. Zootech. Sin. 43:1020-1027. [in Chinese, English abstract]

Yang, Q. L., J. J. Kong, D. W. Wang, S. G. Zhao, and S. B. Gun. 2013. Swine leukocyte antigen- $D Q A$ gene variation and its association with piglet diarrhea in Large White, Landrace and Duroc. Asian Australas. J. Anim. Sci. 26:1065-1071.

Zhou, H. and J. G. H. Hickford. 2008. Clonal polymerase chain reaction-single-strand conformational polymorphism analysis: An effective approach for identifying cloned sequences. Anal. Biochem. 378:111-112. 